6. Конопльов В.В. Теоретичні та практичні аспекти інформаційного забезпечення розробки та прийняття управлінських рішень у сучасній адміністративній діяльності органів внутрішніх справ. Право і Безпека. 2013. № 2. С. 82-86.

7. Плішкін В.М. Теорія управління органами внутрішніх справ: підручник ; за ред. Ю.Ф. Кравченка. Київ : НАВСУ. 1999. 702 с.

8. Прохоренко К.Я. Вимоги до управлінських рішень в діяльності органів Національної поліції. URL: http://109.237.87.242/bitstream/123456789/3267/1/\%D0\%9F\%D1\%80\%D0\%BE\%D1 $\% 85 \% \mathrm{D} 0 \% \mathrm{BE} \% \mathrm{D} 1 \% 80 \% \mathrm{D} 0 \% \mathrm{~B} 5 \% \mathrm{D} 0 \% \mathrm{BD} \% \mathrm{D} 0 \% \mathrm{BA} \% \mathrm{D} 0 \% \mathrm{BE} \% 20 \% \mathrm{D} 0 \% 9 \mathrm{~A} . \% \mathrm{D} 0 \% \mathrm{AF}$. .pdf.

9. Про затвердження Інструкції з діловодства в системі Національної поліції : Наказ Національної поліції України від 20.05.2016 №414. URL : http://tranzit.ltd.ua/nakaz/

10. Уніфікована система організаційно-розпорядчої документації. Вимоги до оформлювання документів ДСТУ 4163-2003 : Наказ Держспоживстандарту від 07.04.2003 p. № 55 . URL: https://zakon.rada.gov.ua/rada/show/v0055609-03.

УДК 342.9

DOI https://doi.org/10.32844/2618-1258.2019.6.23

БІЛОУС О.В.

\title{
ПРИЙОМИ ТА ПРАВИЛА КОНТЕКСТУАЛЬНОГО ТЛУМАЧЕННЯ ПОНЯТЬ ТА КАТЕГОРІЙ АДМІНІСТРАТИВНОГО СУДОЧИНСТВА
}

У статті на підставі узагальненого аналізу наукових, публіцистичних та нормативних джерел визначено прийоми та правила контекстуального тлумачення понять та категорій адміністративного судочинства. Відзначено, що контекстуальне тлумачення понять і категорій адміністративного судочинства - це сукупність прийомів і правил, в основі застосування яких знаходиться контекстуальний аналіз, за допомогою якого встановлюється зміст відповідного поняття або категорії адміністративного процесу з огляду на соціокультурні, правозастосовні та/або ситуаційні контексти їх значення.

Зауважено, що контекстуальне тлумачення розглядається у нерозривному зв'язку із філологічним тлумаченням, оскільки контекстуальний спосіб інтерпретації $€$ своєрідним підвидом філологічного тлумачення, а його основний метод - контекстуальний аналіз - $є$ складовою частиною лінгвістичного аналізу.

На підставі зазначеного сформульовано основні правила та прийоми контекстуального тлумачення понять і категорій адміністративного судочинства, зокрема: прийом гармонійного читання - зміст понять або категорій, що стосуються одного інституту адміністративного процесу або процесу загалом, повинен тлумачитися таким чином, щоб зробити їх сумісними, а не такими, що суперечать один одному; пов'язані слова мають значення одне для одного; поняттям надається те значення, яке 3 ними пов'язується в певному колі осіб; назви та заголовки є допустимими показниками значення відповідного поняття, сформульованого у КАС; якщо в законодавчому акті не визначено тим чи іншим способом значення юридичних термінів, їм слід надавати те значення, в якому вони вживаються в актах тлумачення або в юридичній доктрині, тощо; застосування прийомів ситуаційного контекстуального аналізу до тлумачення оціночних понять.

Ключові слова: адміністративне судочинство, аналіз, поняття, категорії, філологічне тлумачення, контекст.

(с) БІЛОУС О.В. - кандидат юридичних наук, суддя (Верховний Суд) 
In the article, on the basis of the generalized analysis of scientific, journalistic and normative sources, the methods and rules of contextual interpretation of the concepts and categories of administrative justice are defined. It is noted that contextual interpretation of the concepts and categories of administrative justice is a set of techniques and rules, based on which contextual analysis is used, by which the content of the relevant concept or category of administrative process is established based on socio-cultural, law-enforcement and / or situational contexts of their meaning.

It is noted that contextual interpretation is considered inseparably linked to philological interpretation, since the contextual way of interpretation is a kind of subtype of philological interpretation, and its main method - contextual analysis - is an integral part of linguistic analysis.

On the basis of the above, the basic rules and techniques of contextual interpretation of the concepts and categories of administrative justice are formulated, in particular: reception of harmonious reading - the content of concepts or categories that relate to one institution of administrative process or process as a whole should be interpreted in such a way as to make them compatible and not contradictory; related words matter to each other; concepts are given the meaning that is associated with them in a given circle of persons; titles and headings are permissible indicators of the meaning of the relevant concept as defined in the CAS; if the legal act does not define in one way or another the meaning of legal terms, they should be given the meaning in which they are used in the acts of interpretation or in the legal doctrine, etc.; applying the techniques of situational contextual analysis to the interpretation of valuation concepts.

Key words: administrative judiciary, analysis, concepts, categories, philological interpretation, context.

Вступ. Аналіз правозастосовчої практики щодо тлумачення понять та категорій адміністративного судочинства виявив, що поміж традиційних засобів та прийомів інтерпретації, сукупність яких уособлюється у певних способах тлумачення (філологічному, історико-політичному, системному), під час з'ясування та роз'яснення термінологічних конструкцій адміністративного процесу адміністративний суд застосовує й так зване контекстуальне тлумачення. Разом з тим узагальнений огляд доктринальних джерел, присвячених питанням теорії тлумачення норм права та його способам, показав, що вказаний різновид інтерпретації залишається майже недослідженим вітчизняною правовою наукою, що й зумовлює підвищену цікавість як до його правової природи, так і до правил та прийомів його застосування.

Аналіз останніх досліджень і публікацій. Питаннями способів тлумачення норм права приділяється увага у роботах таких вчених правників, як С.С. Алексєєв, Ю.П. Битяк, О.М. Бєляєва, Є.В. Васьковський, Ю.Л. Власов, М.М. Вопленко, О.В. Капліна, В.Я. Карабань, М.С. Кельман, Т.О. Коломоєць, М.М. Коркунов, О.І. Костенко, М.В. Котенко, В.В. Лазарєв, П.І. Люблінський, П.С. Лютіков, М.М. Марченко, Л.Г. Матвєєва, Ж.М. Мельник-Томенко, Д.М. Михайлович, Й.В. Михайловський, М.П. Молибога, П.О. Недбайло, А.С. Піголкін, С.В. Прийма, В.В. Прокопенко, П.М. Рабінович, І.Л. Самсін, А.О. Селіванов, В.М. Сирих, О.Ф. Скакун, Ю.Г. Ткаченко, Ю.М. Тодика, Є.М. Трубецькой, С.Є. Федик, М.В. Цвік, О.Ф. Черданцев, Л.І. Чулінда, С.В. Шевчук, Г.Ф. Шершеневич та інші.

Постановка завдання. Мета статті - на підставі аналізу різноманітних доктринальних джерел визначити прийоми та правила контекстуального тлумачення понять та категорій адміністративного судочинства.

Результати дослідження. Контекстуальне тлумачення нами розглядається у нерозривному зв'язку із філологічним тлумаченням, оскільки контекстуальний спосіб інтерпретації є своєрідним підвидом філологічного тлумачення, а його основний метод - контекстуальний аналіз - $\epsilon$ складовою частиною лінгвістичного аналізу. Окремий його розгляд у межах цього дослідження головним чином зумовлений наявністю в межах КАС України та іншого адміністративно-процесуального законодавства доволі значної кількості так званих оціночних понять, зміст яких має неоднозначний характер.

«Контекст»-1) закінчений за змістом уривок тексту, що дає змогу встановити значення слова або речення, які входять до його складу; 2) про те, що розглядається як ціле, яке зв'язує і пояснює які-небудь явища, факти і таке інше [1, с. 567]. Своєю чергою слово «контекстуальний» $є$ прикметником до слова «контекст» і означає - залежить від контексту, пов'язаний з контекстом [1, с. 567; 2$]$. 
Натомість відповідно до Тлумачного перекладознавчого словника «контекстуальне значення слова»: 1. Багато в чому залежить від характеру семантичного контексту, від семантики поєднаних з ним слів. Контекстуальне значення слова завжди дуже ефективно як семантично, так і стилістично завдяки своїй несподіванці. Воно часто використовується в стилістичних цілях, і тому перекладач стикається з подвійним завданням: він повинен уникати нівелювання і в той же час не порушувати норм перекладу мов. 2. Окремі значення слів, відсутні в їх смисловій структурі і отримані в контексті в зв'язку з особливими умовами вживання, мають перехідний, непостійний характер, з'являються в даний момент і можливі в умовах тільки даного контексту; являє собою найбільш нестійку, рухливу, що коливається в своєму змісті категорію, яка не реалізується в контексті, а виникає в ньому [3, с. 90-91].

Відповідно до загальновживаного розуміння вказаних слів можна цілком логічно припустити, що так зване контекстуальне тлумачення передбачає визначення в окремих випадках необхідних для інтерпретації тої чи іншої норми права контекстів її розуміння, в процесі використання якого застосовується метод контекстуального (контекстного) аналізу.

Контекстуальний аналіз (англ. analysis, contextual; нем. Kontextanalyse) - тип дослідження, за яким поряд з індивідуальними ознаками явища враховуються ознаки контекстів, до яких належить явище; контекстуальні ознаки виступають як незалежні змінні, що впливають на індивідуальні величини або модифікують взаємозв'язки між індивідуальними величинами [4, с. 121].

Як відомо, методика контекстуального аналізу досить поширена під час вивчення художніх творів. О.С. Чирков зазначає, що контекстуальний аналіз художнього твору передбачає наявність певного контексту, в якому твір вивчається та аналізується. На думку мовознавця, розрізняють такі контексти: певної історико-літературної доби (визначенням у ній місця твору); творчості окремого письменника (з визначенням у ній місця твору); певної історичної доби (досліджується повнота відображення доби в літературному творі) [5, с. 34].

Своєю чергою контекстуальне тлумачення норм права передбачає вихід в соціокультурні контексти (аналіз норм в контексті філософських концептів, соціальних цінностей тощо), правозастосовні контексти (тобто враховується судова практика), ситуаційні контексти (обставини справи). Значення інтерпретаційних виразів розглядається не в їх денотативному, а в їх конотативному значенні. Як бачимо, контекстуальне тлумачення, як і будь-які інші способи інтерпретації, для встановлення точного сенсу поняття або категорії використовує логічні прийоми, а також правила філологічного тлумачення. Однак все ж таки присутні і тонкі грані, що відрізняють цей спосіб тлумачення від більш загального, родового для нього - філологічного.

Наприклад, у рамках філологічного тлумачення використовуються філолого-лінгвістичні прийоми і правила для визначення сенсу слів і виразів, і якщо їх було недостатньо для досягнення результату, тлумач, якщо це доречно, може вдатися до контекстного тлумачення, в якому йдеться насамперед про виявлення сенсу поняття в контексті окремо взятого спору або фактичних обставин справи, що можуть істотно варіювати зміст поняття, що інтерпретується.

Контекстуальний аналіз правових норм КАС України, що містять поняття і категорії, досить рідко вдається до пошуку різноманітних можливих соціокультурних контекстів використання поняття, що тлумачиться. Зазвичай такі контексти можуть бути предметом дослідження під час тлумачення відповідних правових норм Конституційним Судом України, який відштовхується в тому числі і від різного роду філософських концептів, і соціокультурних контекстів під час визначення змісту того чи іншого правового положення. Яскравим прикладом може слугувати правотлумачна позиція Суду на рахунок змісту принципу верховенства права, викладена в його окремих рішеннях. Так, наприклад, КСУ роз'яснив, що одним із проявів верховенства права $\epsilon$ те, що право не обмежується лише законодавством як однією з його форм, а включає й інші соціальні регулятори, зокрема норми моралі, традиції, звичаї тощо, які легітимовані суспільством і зумовлені історично досягнутим культурним рівнем суспільства. Всі ці елементи права об'єднуються якістю, що відповідає ідеології справедливості, ідеї права, яка значною мірою дістала відображення в Конституції України. Таке розуміння права не дає підстав для його ототожнення із законом, який іноді може бути й несправедливим, у тому числі обмежувати свободу та рівність особи. Справедливість - одна з основних засад права, $є$ вирішальною у визначенні його як регулятора суспільних відносин, одним із загальнолюдських вимірів права. Зазвичай справедливість розглядають як властивість права, виражену, зокрема, в рівному юридичному масштабі поведінки й у пропорційності юридичної відповідальності вчиненому правопорушенню [6].

В інших своїх рішеннях КСУ звертав увагу на інші філософські та ціннісні категорії, що лежать в основі принципу верховенства права, зокрема такі, як ефективність, розмірність, пропорційність тощо: 
«На основі системного аналізу оспорюваних положень кодексів Конституційний Суд України дійшов висновку, що вони грунтуються на принципі верховенства права, зокрема на таких його складниках, як ефективність мети і засобів правового регулювання, розумність та логічність закону [7];

«Конституційний Суд України виходить із того, що додержання конституційних принципів соціальної і правової держави, верховенства права (стаття 1, частина перша статті 8 Основного Закону України) зумовлює здійснення законодавчого регулювання суспільних відносин на засадах справедливості та розмірності з урахуванням обов'язку держави забезпечувати гідні умови життя кожному громадянину України [8];

«Одним із елементів верховенства права є принцип пропорційності, який у сфері соціального захисту означає, зокрема, що заходи, передбачені в нормативно-правових актах, повинні спрямовуватися на досягнення легітимної мети та мають бути співмірними з нею» [9].

Що стосується Верховного Суду, у його практиці також відомі окремі рішення, в яких суд, абстрагуючись від надмірно формалізованих підходів до вирішення спорів нижчими судами та піддаючи їх критиці, намагався виходити з контексту філософської теорії людиноцентризму і ії впливу на право. Так, викладаючи своє розуміння положень ст. 3 Конституції України, Велика Палата Верховного Суду зазначила, що із конституційних норм про визнання людини, ії життя і здоров'я, честі і гідності, недоторканності і безпеки найвищою соціальною цінністю, спрямування змісту і спрямованості діяльності держави правами, свободами людини та їх гарантіями, а також відповідальність держави за свою діяльність перед людиною та визначення основним обов'язком держави, випливає те, що, зокрема, встановлюючи ті чи інші правила поведінки, держава має в першу чергу дбати про потреби людей, утримуючись за можливості від встановлення таких правил, які негативно сприйматимуться тими чи іншими групами суспільства. Встановлення таких правил може бути виправдане тільки наявністю переважаючих суспільних інтересів, які не можуть бути задоволені в інший спосіб, але і в цьому разі має бути дотриманий принцип пропорційності [10].

Під час пошуку правозастосовних контекстів і використання їх застосовано до понять, що тлумачаться, суб'єкт інтерпретації спирається на існуючу судову практику (зазвичай судів вищих інстанцій). В даному випадку особливо важливо підібрати найбільш відповідний правозастосовчий акт, прийнятий за схожим спором, у рамках якого юрисдикційний орган, який «розбирає» спір, тлумачив відповідне поняття і застосовував його до розглянутого типу суспільних відносин. Таким чином, під час правозастосовчого контекстного тлумачення використовується судова практика, поняття, що тлумачиться, досліджується в контексті сформованих підходів до його розуміння тощо.

Своєю чергою ситуаційний контекст, прийоми якого допомагають визначити зміст оціночних понять, дозволяє суб'єкту тлумачення частково або загалом абстрагуватися від існуючої судової практики та враховувати першочергово конкретні обставини справи. 3 огляду на них суд, скориставшись адміністративним розсудом, може витлумачити оціночні поняття та його ознаки, що змінюються в контексті саме зазначених сторін у справі, окремих фактів, правових і фактичних підстав спору тощо. Природно, що ситуаційний контекст зазвичай застосовується до кожного окремо взятого спору.

Як приклад використання прийому контекстуального аналізу можна навести таку позицію Верховного Суду. Так, у своєму рішенні від 16.10.2018 року у справі №9901/637/18 про визнання протиправним та скасування рішення Вищої кваліфікаційної комісії суддів України (далі за текстом - ВККС) та зобов'язання вчинити певні дії, постановляючи рішення, звернув увагу, що рішення органу має бути вмотивованим. «Відсутність мотивів у такому рішенні $\epsilon$ законодавчо визначеною підставою для його оскарження і наступного скасування. Це прямо закріплено у пункті 4 частини 3 статті 88 Закону України 02 червня 2016 року «Про судоустрій і статус суддів». Наведені норми у своїй сукупності призводять Суд до переконання, що законодавець вимагає наявність мотивів як обов'язкового складника ухвалених за результатами кваліфікаційного оцінювання рішень і гарантії дотримання прав особи, щодо якої таке проводиться». ВС звернув увагу, що в оскаржуваному Рішенні наведений лише перелік засобів встановлення відповідності судді займаній посаді (результати іспиту, тестування, дослідження досьє, співбесіди), а також вказані бали позивача за кожним з критеріїв, однак відсутні мотиви для прийняття рішення щодо кожного з вказаних критеріїв та аргументи ВККС на користь прийняття чи відхилення доводів та доказів позивача та виставлення саме такої кількості балів [11].

Здійснивши контекстуальний аналіз слова «мотив», при цьому проаналізувавши підзаконні нормативно-правові акти, урахувавши конкретні обставини справи та зміст оскаржуваного Pi- 
шення, ВС дійшов висновку, що «Прозорість адміністративних процедур є ефективним запобіжником державному свавіллю. Вмотивоване рішення демонструє особі, що вона була почута, дає стороні можливість апелювати проти нього. Лише за умови винесення обгрунтованого рішення може забезпечуватися належний публічний та, зокрема, судовий контроль за адміністративними актами суб'єкта владних повноважень. < .. > Про дотримання членами Комісії означеної процедури свідчитиме належна мотивація його висновку: встановлення обставин, що мають значення для правильного вирішення кожного $з$ перелічених у Главі II Положення № 143/зп-16 (п.п. 1-10) питань; посилання на докази, якими такі обставини обгрунтовані, із зазначенням причин їх прийняття чи відхилення; оцінка доводів та аргументів особи, щодо якої застосовується процедура оцінювання; норми права, що застосовані, і ті, що не застосовані, з викладенням мотивів їх незастосування. I навпаки, ненаведення мотивів прийнятих рішень «суб'єктивізує» акт державного органу і не дає змоги суду встановити дійсні підстави та причини, з яких цей орган дійшов саме таких висновків, надати їм правову оцінку та встановити законність, обгрунтованість, пропорційність рішення. <..> Крім того, враховуючи наведені вище норми Конституції України та міжнародні рекомендації, у рішенні за результатами кваліфікаційного оцінювання має міститись висновок про те, за яким саме критерієм (компетентності, професійної етики або доброчесності) суддя не відповідає займаній посаді, адже суддя підлягає звільненню з займаної посади винятково у разі, якщо він не відповідає займаній посаді хоча б за одним з вказаних вище критеріїв: компетентності, професійної етики або доброчесності, і неминучий висновок 3 процесу оцінювання полягає у тому, що суддя не здатний здійснювати правосуддя на «об’єктивно визначеному мінімально прийнятному рівні».

Отже, посилання Комісії лише на засоби встановлення відповідності судді займаній посаді та кількість виставлених за результатами кваліфікаційного оцінювання балів не дають змоги встановити, за яким конкретно критерієм позивач не відповідає займаній посаді, жодним чином не дозволяє встановити дійсних підстав, з яких виходила ВККС під час ухвалення Рішення, i мотивів його прийняття. Зазначене рівною мірою стосується усіх частин оскаржуваного рішення, 3 огляду на що є підставою до його скасування в цілому» [11].

Висновки. 3 огляду на вищевикладене контекстуальне тлумачення понять і категорій адміністративного судочинства можна визначити як сукупність прийомів і правил, в основі застосування яких знаходиться контекстуальний аналіз, за допомогою якого встановлюється зміст відповідного поняття або категорії адміністративного процесу з огляду на соціокультурні, правозастосовні та/або ситуаційні контексти їх значення.

На підставі зазначеного сформулюємо основні правила та прийоми контекстуального тлумачення понять і категорій адміністративного судочинства, зокрема:

- прийом гармонійного читання - зміст понять або категорій, що стосуються одного інституту адміністративного процесу або процесу в цілому, повинен тлумачитися таким чином, щоб зробити їх сумісними, а не такими, що суперечать один одному;

- пов'язані слова мають значення одне для одного;

- поняттям надається те значення, яке з ними пов'язується в даному колі осіб;

- назви та заголовки є допустимими показниками значення відповідного поняття, сформульованого у КАС;

- якщо в законодавчому акті не визначено тим чи іншим способом значення юридичних термінів, їм слід надавати те значення, в якому вони вживаються в актах тлумачення або в юридичній доктрині тощо. Зокрема, КАС України не містить визначення таких понять, як «добросовісно», «розсудливо», зміст яких розкривається під час правозастосування або в науково-практичних коментарях до КАС України, чи в наукових публікаціях, присвячених цим питанням;

- застосування прийомів ситуаційного контекстуального аналізу до тлумачення оціночних понять. Оціночним поняттям, враховуючи їх абстрактний характер, неможливо на законодавчому рівні надати однозначного та повного змісту, тому вони мають варіативний зміст, який визначається юрисдикційним суб'єктом залежно від суті того чи іншого публічно-правового спору. У таких випадках суд застосовує загальновідомі прийоми та методи логічного мислення (аналіз, синтез, індукція, дедукція тощо) із урахуванням конкретних обставин справи (ситуаційний контекст). Зокрема, у таких поняттях, як «достовірні докази», «достатні докази», законодавцем наведено лише ключові їх ознаки із подальшою вказівкою на те, що, наприклад, питання про достатність доказів для встановлення обставин, що мають значення для справи, суд вирішує відповідно до свого внутрішнього переконання. 


\section{Список використаних джерел:}

1. Великий тлумачний словник сучасної української мови / уклад. і голова ред. В.Т. Бусел. Київ ; Ірпінь : ВТФ «Перун», 2001. 1440 с.

2. Словарь лингвистических терминов. URL: http://www.textologia.ru/slovari/ lingvisticheskie-terminy/kontekstualniy/?q $=486 \& n=726$

3. Нелюбин Л.Л. Толковый переводоведческий словарь. 3-е изд., перераб. Москва : Флинта : Наука, 2003. 320 с.

4. Большой толковый социологический словарь. (В 2-х томax; «Collins»). / Пер. с англ. Москва : Вече, АСТ, 2001. 544с. (т. 2 П-Я). Москва : Вече, АСТ, 2001. 528c.

5. Чирков О.С. Основи теорії літератури. Частина перша (у співавторстві з М. Дубиною). Київ, 1997. 63 с.

6. Рішення Конституційного Суду України у справі за конституційним поданням Верховного Суду України щодо відповідності Конституції України (конституційності) положень статті 69 Кримінального кодексу України (справа про призначення судом більш м'якого покарання) від 2 листопада 2004 року № 15-рп/2004

7. Рішення Конституційного Суду України у справі за конституційним зверненням товариства з обмеженою відповідальністю «Пріма-Сервіс» ЛТД щодо офіційного тлумачення положення пункту 7 частини третьої статті 129 Конституції України та за конституційним поданням 54 народних депутатів України щодо відповідності Конституції України (конституційності) окремих положень частини шостої статті 12, частини першої статті 41 Кодексу адміністративного судочинства України, частини другої статті 197 Цивільного процесуального кодексу України, а також частини восьмої статті 81-1 Господарського процесуального кодексу України (справа про фіксування судового процесу технічними засобами) від 8 грудня 2011 року № 16-рп/2011

8. Рішення Конституційного Суду України у справі за конституційними поданнями 49 народних депутатів України, 53 народних депутатів України і 56 народних депутатів України щодо відповідності Конституції України (конституційності) пункту 4 розділу VII «Прикінцеві положення» Закону України «Про Державний бюджет України на 2011 рік» від 26 грудня 2011 року № $20-$ рп/2011.

9. Рішення Конституційного Суду України у справі за конституційним поданням правління Пенсійного фонду України щодо офіційного тлумачення положень статті 1, частин першої, другої, третьої статті 95, частини другої статті 96, пунктів 2, 3, 6 статті 116, частини другої статті 124, частини першої статті 129 Конституції України, пункту 5 частини першої статті 4 Бюджетного кодексу України, пункту 2 частини першої статті 9 Кодексу адміністративного судочинства України в системному зв'язку з окремими положеннями Конституції України від 25 січня 2012 року № 3-рп/2012.

10. Постанова Верховного Суду від 19 вересня 2018 року у справі № 806/3265/17 про визнання протиправною бездіяльності та зобов'язання вчинити певні дії. URL: https://verdictum. ligazakon.net/document/76822787.

11. Рішення Верховного Суду від 16 жовтня 2018 року у справі №9901/637/18 про визнання протиправним та скасування рішення та зобов'язання вчинити певні дії. URL: https://verdictum.ligazakon.net/document/77361545. 